ISSN 1392-3196 / e-ISSN 2335-8947

Zemdirbyste-Agriculture, vol. 104, No. 1 (2017), p. 85-94

DOI $10.13080 /$ z-a.2017.104.012

\title{
Effects and management strategies to mitigate drought stress in oilseed rape (Brassica napus L.): a review
}

\author{
Muhammad Aown Sammar RAZA ${ }^{1}$, Abdul Manan SHAHID ${ }^{1}$, Muhammad Farrukh SALEEM ${ }^{2}$, \\ Imran Haider KHAN ${ }^{3}$, Salman AHMAD ${ }^{1}$, Muhammad ALI ${ }^{1}$, Rashid IQBAL ${ }^{1}$ \\ ${ }^{1}$ University College of Agriculture and Environmental Sciences, \\ The Islamia University of Bahawalpur, Pakistan \\ E-mail: aown_samar@yahoo.com \\ ${ }^{2}$ University of Agriculture \\ Faisalabad, Pakistan \\ ${ }^{3}$ College of Agriculture, Ghazi University \\ Dera Ghazi Khan, Pakistan
}

\begin{abstract}
Oilseed rape (Brassica napus L.) is an important oilseed crop worldwide. Drought is the most detrimental environmental factor affecting the crop plants from germination up to maturity. A complete perspective of the effect of drought is crucial in understanding the influence of climate variability on rape cultivation. Water deficit stress affects morphology, physiology and development of rape crop. The aim of this article is to present an outline of the effects of drought stress on the growth, physiological processes, yield and quality parameters of rape crop. When drought stress occurs at critical stages, both short and long term, it can adversely affect important growth and physiological processes like leaf area, root growth, shoot growth, excised leaf water loss (ELWL), relative water content (RWC), photosynthesis and water use efficiency (WUE) by disturbing stomatal adjustment, producing reactive oxygen species (ROS), lowering stomatal conductance and destroying the chlorophyll and other pigments. Rape is more susceptible to water deficit stress during reproductive stages which ultimately affect the yield and oil quality. Some important management strategies for drought mitigation in rape, including use of compatible solutes, nutrients, plant growth regulators, different planting methods are also mentioned and discussed in this review paper.
\end{abstract}

Key words: Brassica napus, drought stress, effects, management.

\section{Introduction}

After soybean (Glycine max L.) and palm oil (Elaeis guineensis L.), rape (Brassica napus L.) is ranked $3^{\text {rd }}$ most essential source of plant oil in the world (Reyes, $2007)$. The oil contents in rapeseed range from $40 \%$ to $42 \%$. Rapeseeds contain more than $25 \%$ protein. Rape oil contains $61 \%$ oleic acid, $8.8 \%$ linoleic acid and has better quality as compared to other oil seeds. Among all vegetable oils, rape contains very low saturated fat contents so that demand of rape oil is increasing day by day for diet conscious consumers (Rastegar, 2004).

Among all abiotic stresses, drought stress is the major cause of poor crop yield (Table 1). It is estimated that $40 \%$ to $60 \%$ of total crop yield losses in the world are due to drought stress (Shao et al., 2008). In rape, water deficit stress has deleterious effects during both vegetative and reproductive growth stages. In rapeseed, drought stress was more detrimental during reproductive growth than vegetative growth (Ghobadi et al., 2006).

The biggest task in the upcoming years will be growing crops with less water availability, especially in
Table 1. Mean comparisons of germination characters of rapeseeds under control and osmotic stress conditions (Heshmat et al., 2011)

\begin{tabular}{ccc}
\hline Stress & Germination time, day & Germination co-efficient \\
\hline 0 & $2.487 \mathrm{c}$ & $0.411 \mathrm{a}$ \\
-3 & $2.504 \mathrm{c}$ & $0.402 \mathrm{ab}$ \\
-6 & $2.622 \mathrm{bc}$ & $0.389 \mathrm{ab}$ \\
-9 & $2.834 \mathrm{~b}$ & $0.364 \mathrm{~b}$ \\
-12 & $3.271 \mathrm{a}$ & $0.318 \mathrm{c}$ \\
\hline
\end{tabular}

Note. Mean having same letters are not different significantly from each other $\left(\mathrm{LSD}_{0.05}\right)$.

areas which have inadequate water recourses. So, there is a need to cope with this problem by adopting strategies which result in more economical and more efficient use of water (Nasrullah et al., 2011). Many strategies such as foliar applied nutrients (Raza et al., 2012 a), growth regulators (Ahmadi et al., 2015), compatible solutes 
(Raza et al., 2012 b), mulching (Ahmad et al., 2015) and different sowing methods (Aiken et al., 2015) have been developed to cope with water deficit conditions.

Effects of drought stress on various morphological characteristics of rape. Drought impairs various morphological traits like reduction in cell division and expansion, less leaf growth, leaf area, plant height, root to shoot ratio, number of nodes, number of branches, seed per pod and ultimately less yield. Figure indicates the effects of drought on various morphological and physiological attributes of plants.
Germination. Germination and seedling establishment are important for determination of final density of plants per unit area which ultimately leads towards higher crop yield. Many reports showed that seeds tolerant to drought stress during germination stage have better growth at seedling stage and produce strong root system (Waheed, 2014).

Water is a prerequisite for germination. Rape is susceptible to water stress during germination stage. Germination rate and percent decreased with increasing water deficit stress (Shahverdikandi et al., 2011).

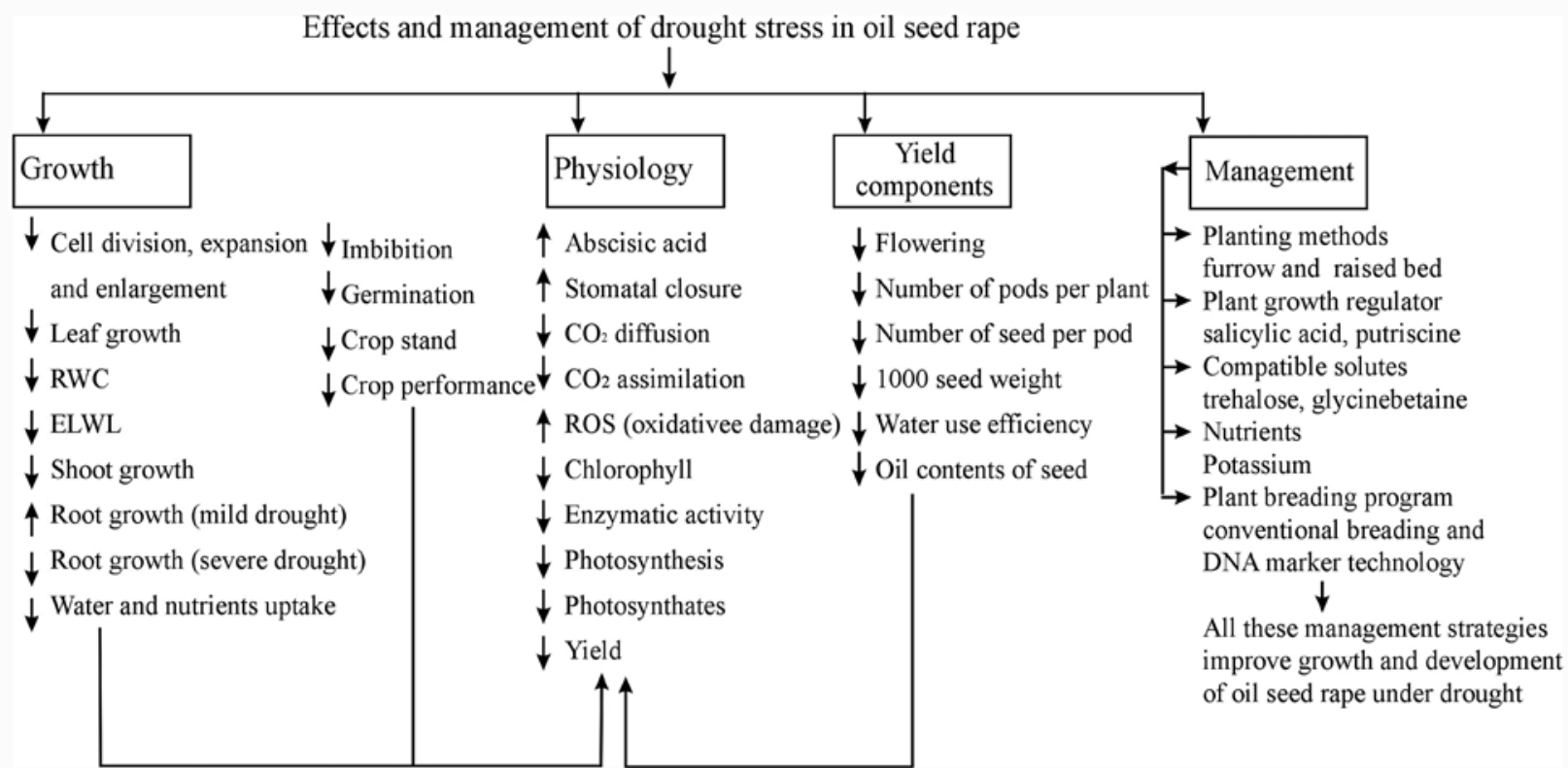

Figure. Effects and management of water deficit stress on various morphological, physiological and yield attributes of oilseed rape

It is due to less water availability for imbibition (first step of germination process in which water is entered into the seed) than required for activating the biochemical processes in the seed necessary for germination (Resh, 2012). Drought stress decreased germination percent, root and shoot length in rape (Yang et al., 2007). Germination time and germination co-efficient of rapeseeds were observed under control and different osmotic potential levels and it was found that with increase in osmotic potential germination time increased while values of germination co-efficient decreased (Table 2).

Shoot growth. Growth is accomplished by cell expansion and enlargement and these processes are very sensitive to water deficit stress. Stem growth often decreased under water deficit stress (Sharp, LeNoble, 2002). Under water deficit stress reduction in shoot growth was due to imbalance in water relations which leads to less cell expansion and enlargement and ultimately stunted rape plant growth (Gul, Ahmad, 2004). Stem elongation to flowering stage of rape is most sensitive to water deficit stress (Hosseini, Hassibi, 2011). Higher stem height of rape was recorded in control treatment and stem height decreased with decrease in irrigation level (Hadi et al., 2014). Less shoot length and biomass was recorded in different rape varieties grown under limited water conditions (Ashraf et al., 2013). In response to drought, some chemical compounds are produced in plants which reduce plant growth (Reddy et al., 2004). It is well known that higher concentration of abscisic acid in plants under drought conditions results in less plant height (Achard et al., 2006). It is mainly due to inhibitory effects of abscisic acid on cell growth, which finally leads to stunted growth. Qaderi et al. (2006) also reported less plant height in different rape varieties under water deficit conditions, due to the more accumulation of abscisic acid as compared to control treatment. Higher number of branches per plant, plant height and shoot dry weight was recorded in sufficiently watered rape plant as compared to mild and severe drought affected rape plants (Mehanna et al., 2013).

Root growth. Drought affects root growth as that of shoot growth. However, root growth is less sensitive to drought stress as compared to the stem growth (Chaves et al., 2002). Uptake of water by plants under water deficit conditions mainly depends upon the extension and distribution of roots system (Zhang et al., 2014). With increase in intensity of drought root length of rape decreases (Hadi et al., 2014). Rape root biomass also decreased with increase in drought level. Less root length and biomass was found in drought affected rape plants (Mehanna et al., 2013). Under mild drought stress root length, root fresh and dry weight increased in rape plants as compared to control treatment. However, under severe drought conditions root length and weight were less as compared to the drought (Ashraf et al., 2013). Similarly, Mehanna et al. (2013) also recorded more root length and root dry weight in rape treated with mild drought stress. More root length under drought was due to the 
more partitioning of assimilates towards the roots at the expense of shoot growth (Kage et al., 2004). This root elongation under drought stress may help plant to obtain water from deeper soil layers and in this way mitigate drought. So, increase in root to shoot ratio of plants is a common indicator when grown under water deficit conditions (Jabeen et al., 2008).

Leaf growth. One of the important determinants of crop yield is leaf as it directly influences the assimilates production during photosynthesis (Amanullah et al., 2009). Leaf expansion is sensitive to water availability and is adversely affected by water deficit stress. Leaf area of rape decreases under drought stress and with increase in intensity of drought more reduction in leaf area occurs (Gul, Ahmad, 2004). Drought was applied at different growth stages to rape and significant decrease in leaf area was observed at all growth stages as compared to control treatment (Raza et al., 2015 a). Reduction in leaf area under water deficit conditions is mainly due to less leaf expansion and leaf area adjustment process (Farouk, 2011). Leaf osmotic potential also decreased in all tested rape varieties under water deficit conditions (Khan et al., 2010). It is due to the more accumulation of solutes in leaf cells (Bajji et al., 2001). Similar effects of drought on osmotic potential in rape leaves were reported by Kumar and Singh (1998). Moreover, leaf abscission and senescence also accelerated when plants were grown under water deficit conditions. It is due to the increasing concentration of abscisic acid in leaves under water deficit conditions (Munne-Bosch, Penuelas, 2003).

\section{Effects of drought stress on various physiological characteristics of rape}

Drought stress negatively affects many physiological plant processes, such as photosynthesis, transpiration, stomatal conductance, chlorophyll contents and metabolite accumulation which cause considerable reductions in plant productivity (Reddy et al., 2004). Higher electron leakage in photosynthetic and respiratory processes under drought stress induced oxidative stress in the plant cell resulting in reactive oxygen species (ROS) production (Tohidi-Moghadam et al., 2009). The degree of damage due to drought stress depends upon the type of genotype, intensity and duration of stress and developmental stage of the plant (Robertson, Holand, 2004).

Chlorophyll contents. Chlorophyll concentration can be used as an indicator for source capacity to synthesize photosynthates (Zhang et al., 2007). So decrease in chlorophyll concentration is a limiting factor for photosynthesis. Stress injury causes variation in chlorophyll contents and it is a common symptom in drought stressed plants (Majumdar et al., 1991). In plants, water deficit stress causes reduction in leaf chlorophyll contents. The decrease in chlorophyll contents under water deficit stress is mainly due to the production of ROS that damage the chloroplasts (Gill, Tuteja, 2010). Decrease in activity of chlorophyllase (enzyme involved in chlorophyll synthesis) under water deficit conditions is also a major reason for degradation of chlorophyll under drought (Ashraf et al., 2013). In Brassica napus cultivars, drought stress causes decrease in chlorophyll $a+b$ contents by $38 \%$ as compared to the sufficiently watered plants (Sharma et al., 1993). Chlorophyll $a$ is more sensitive to drought stress than chlorophyll $b, 57 \%$ reduction in chlorophyll $a$ contents, $31 \%$ reduction in chlorophyll $b$ contents and $47 \%$ reduction in chlorophyll $a: b$ ratio in rape were recorded under water deficit as compared to the control. Similar effect of drought on chlorophyll contents and carotenoid contents were reported by Habibi (2015). Lower chlorophyll contents in rape under water deficit stress are due to more destruction and less biosynthesis of chlorophyll (Alam et al., 2014). Zhang et al. (2014) reported higher leaf chlorophyll contents in sufficiently watered rape plants as compared to drought affected plants.

Photosynthesis. Photosynthesis is the key process which contributes towards the final yield of the crop. Rate of photosynthesis decreased when plants were exposed to drought stress (Huax et al., 1997). Drought stress results in increased salt concentration in the soil and around the root zone of the plant which ultimately causes ex-osmosis (flow of water out of plant cells). This in turn/causes the solute concentration in plant cells to be increased, thus lowering water potential and disrupting membranes along with essential processes like photosynthesis (Ludlow, Muchow, 1990). Osmotic stress causes the closure of stomata. Stomatal control of water loss has been identified as an early event in plant response to drought leading to limitation of carbon dioxide uptake by the leaves (Martinez et al., 2007). The initial decrease in photosynthesis under water stress condition is due to change in $\mathrm{CO}_{2}$ conductance (Emam, Niknejad, 2004). With increase in irrigation intervals stomatal resistance also increases. Ardestani and Rad (2012) recorded $70.67 \%$ and $65.72 \%$ more stomatal in different rape cultivars when drought was applied at vegetative growth stage as compared to control treatment. Similarly $11.57 \%$ and $11.73 \%$ higher stomatal resistance was recorded when drought was applied at siliqua formation stage. Nasab et al. (2014) reported 16\% less stomatal conductance in drought affected rape compared to control one. Stomata closure under drought stress is either due to the decline in leaf turgor and water potential or due to low atmospheric humidity.

Droughtwasappliedatdifferentrapeseedvarieties under water field conditions and a decrease in the leaf water potential, stomatal conductance, crop temperature stability, leaf relative water content (RWC) and increase in leaf temperature and specific leaf weight (dry matter per unit leaf area) were recorded in all varieties of rapeseed (Pasban Eslam et al., 2000). All these changes disturb the normal process of photosynthesis, leading towards less production of photosynthates and ultimately poor yield (Mondal, Khajuria, 2000). Drought stress also decreases the activity of Rubisco (Silva et al., 2012). Under drought stress 2-carboxyarabinitol-phosphate is formed in many plants which binds strongly with Rubisco and restricts its catalytic activity (Parry et al., 2002). When plants were exposed to drought carboxylation efficiency of Rubisco, regeneration of ribulose-1,5-bisphosphate (RuBP) and activity of adenosine triphosphate (ATP)-synthase also decreased, resulting in a decline in photosynthetic rate (Tezara et al., 1999). Under water deficit stress over production of electrons through electron transport chain also takes place due to over excitement of reaction centres of photosystem II. These electrons damage the photosynthetic apparatus and ultimately process of photosynthesis (Gill, Tuteja, 2010). 
Drought also causes synthesis of abscisic acid (ABA) in plants. Higher ABA concentration induces stomatal closure, which ultimately decreases the photosynthesis (Ashraf, Harris, 2013). Under water deficit condition, higher amount of ABA is produced in rape which minimizes the inflow of carbon dioxide into the leaf by promoting stomatal closure and reduces the photosynthetic activity of rape (Habibi, 2015). Moreover, under water deficit conditions deficiencies of some essential nutrients especially of potassium (K) have also been reported to decrease stomatal conductance of leaves (Mengel, Kirkby, 2001). Thus water deficit stress decreases the photosynthesis by impairing the stomatal oscillation, activities of enzymes, disturbing the process of electron transport chain and over production of growth inhibiting hormone the ABA.

Oxidative damage. Drought stress consistently leads to oxidative stress in plant cells, due to a higher leakage of electrons towards $\mathrm{O}_{2}$ during the photosynthetic and respiratory processes, which ultimately results in generation of ROS (Asada, 1999). At higher concentrations, ROS are very harmful for the plants. When their concentration crosses the threshold limit, ROS such as superoxide radical $\left(\mathrm{O}^{-}\right)$, hydrogen peroxide $\left(\mathrm{H}_{2} \mathrm{O}_{2}\right)$, hydroxyl radical $\left(\mathrm{OH}^{-}\right)$and singlet oxygen $\left(\mathrm{O}^{-1}\right)$ can directly attack the various cellular organelles like mitochondria, chloroplast, membrane lipid, inactive certain metabolic enzymes and nucleic acids, leading to disfunctioning of cell and ultimately cell death (Mittler, 2002). ROS destroy the chlorophyll which results in decrease in photosynthesis and ultimately less assimilates produced (Ebrahimian, Bybordi 2012). Lower seed yield was recorded in rape plants damaged by the activities of ROS as compared to the plants in control treatment under laboratory conditions (Abili, Zare, 2014). Drought also induces higher $\mathrm{H}_{2} \mathrm{O}_{2}$ production in rape which increases lipid peroxidation (Mirzaee et al., 2013). Increase in lipid peroxidation under water deficit stress was also reported by Sánchez-Rodríguez et al. (2012) in tomato (Solanum lycopersicum) plants.

Higher absicsic acid production under water deficit conditions results in stomatal closure. This situation leads to more production of various ROS including superoxide. Superoxide is also an important member of ROS and impairs the normal functions of rape by oxidizing photosynthetic pigments (chlorophyll and carotenoids), lipids, nucleic acids and by damaging other cell organelles (Kheradmand et al., 2014).

Relative water content (RWC). The leaf RWC indicates the leaf water status and is considered to be an important marker of drought tolerance in plants (Sánchez-Blanco et al., 2002). RWC has a close relation with leaf water potential and cell volume. Many leaf physiological traits such as leaf turgor, stomatal conductance, transpiration and photosynthesis are directly or indirectly influenced by leaf RWC (Ober et al., 2005). A reduction of $50 \%$ in net photosynthesis was recorded when RWC was less than $80 \%$ (Patil et al., 2011). More stomatal resistance was also recorded with less RWC in rape plants under water deficit conditions. A decrease of $4.28 \%$ and $14 \%$ in RWC of rape leaves increased stomatal resistance from 1.89 to 2.94 and $5.96 \mathrm{~s} \mathrm{~cm}^{-1}$, respectively. Moreover, plant canopy temperature was also higher in plants with less RWC (Ardestani, Rad, 2012). Leaf RWC was significantly decreased by drought stress. Different rape varieties were grew under various irrigation regimes and reduction in value of RWC of rape was recorded with depleting irrigation. RWC was decreased in both drought tolerant and sensitive varieties. However, greater reduction was observed in drought sensitive varieties (Ullah et al., 2012). Higher value of leaf RWC is an important character which influences the continual growth of rapeseed under drought stress and ultimately leads to higher yield (Kumar, Singh, 1998). So, lower values of leaf RWC under drought suppress the growth by decreasing the stomatal conductance, transpiration and photosynthesis.

Excised leaf water loss (ELWL). Most commonly used parameters to evaluate the leaf water stress are ELWL and leaf water potential (Jones et al., 1991). ELWL shows the cuticular thickness because after removing from the plant, leaves lose their water through epidermis therefore, difference in values of excised leaf water loss is due to the variation in cuticular thickness. Both waxiness and cuticular thickness of leaf affect the transpiration (Haque et al., 1992). So, lower rate of transpiration and excised leaf water loss are important criteria for selection of crop plants against drought stress (Rahman et al., 2000). It has been observed that the species having low rate of water loss through leaf cuticle are better adapted to dry environment. More ELWL was observed under water deficit stress. In different mustard varieties higher excised leaf water loss was recorded when temperature exceed the normal range (Ram et al., 2015). Similarly, Soomroo et al. (2011) reported higher values of ELWL in cotton plants exposed to various drought levels as compared to the control treatment. ELWL showed negative correlation with various traits like stomatal size, stomatal frequency and relative water content. However, the absence of the correlation of ELWL with other studied traits shows that the genes for ELWL segregate independent of the other traits so plants with lower ELWL (having drought resistance) may be selected for good quality and yield traits (Malik et al., 2006).

\section{Effects of drought stress on various reproductive characteristics of rape}

Drought stress decreases crop productivity by disturbing the source and sink relationship. Rape is more susceptible to water stress during pre-flowering (10-12 days before anthesis) and flowering stages as drought applied at these stages results in fewer flowers, siliquae and seed sterility (Lizana et al., 2006). Drought stress at flowering stage adversely affects pod formation and seed size, which ultimately results in less economic yield (Johnston et al., 2002).

Yield components of rapeseed are significantly affected by irrigation intervals. Water deficit stress decreased the number of siliques per plant (Hassanzadeh et al., 2005). Number of pods per plant, seed yield and oil content of rape decreased under drought stress (Rahnema, Bakhshandeh, 2006). Malcolm and Doug (2002) concluded that water deficit conditions resulted in fewer flowers and seeds and small seed size. There exists a significant correlation between the number of siliquae per plant and the seed yield. Lower number of primary and secondary branches, number of pods per plant and number of seed per plant was recorded in different $B$. napus cultivars grown under drought stress and greater 
reduction in seed yield was recorded when drought was applied during flowering stage (Zakirullah et al., 2000; Nasri et al., 2008). Flowering is the most sensitive stage to drought stress, probably due to susceptibility of pollen development, anthesis and fertilization leading to lower seed yield (Faraji et al., 2009).

Water deficit stress adversely affects water use efficiency (WUE) and uptake of macro and micro nutrients (Munoz-Perea et al., 2007). Water deficit stress decreased plant biomass, days to maturity, number of siliqua and seed, seed weight, seed yield and harvest index of rape (Lizana et al., 2006). Khalid et al. (2006) observed the effect of different irrigation regimes on the yield attributes of rape and reported lower number of pods per plant, number of seeds per pod, 1000 seed weight and seed yield in less irrigated treatments as compared to fully irrigated treatment (Table 2).

Seed yield. Yield of rape is determined by a combination of factors like number of branches and pods per plant, seeds per pod and weight and size of seed. Many studies revealed that drought affects yield by disturbing leaf photosynthesis and plant water relations (Mondal, Khajuria, 2000), nutrient relation (Ardestani, Rad, 2012), dry matter partitioning (Ashraf et al., 2013), biological yield, seed yield and oil contents in rape (Ghobadi et al. 2006). Water deficit stress decreases the

Table 2. Effect of different irrigation levels on yield attributes of oilseed rape (Raza et al., 2015 a)

\begin{tabular}{|c|c|c|c|c|}
\hline $\begin{array}{l}\text { Irrigation } \\
\text { level }\end{array}$ & $\begin{array}{l}\text { No. of pods } \\
\text { per plant }\end{array}$ & $\begin{array}{c}\text { No. of seeds } \\
\text { per pod }\end{array}$ & $\begin{array}{c}1000 \text { seed weight } \\
\mathrm{g}\end{array}$ & $\begin{array}{c}\text { Seed yield } \\
\mathrm{kg} \mathrm{ha}^{-1}\end{array}$ \\
\hline Control & $241.50 \mathrm{a}$ & $20.50 \mathrm{a}$ & $3.8 \mathrm{a}$ & $2550.00 \mathrm{a}$ \\
\hline 3 irrigations & $228.75 \mathrm{~b}$ & $17.50 \mathrm{~b}$ & $3.6 \mathrm{~b}$ & $2430.00 \mathrm{~b}$ \\
\hline 2 irrigations & $213.25 \mathrm{c}$ & $15.25 \mathrm{c}$ & $3.3 \mathrm{c}$ & $2232.50 \mathrm{c}$ \\
\hline 1 irrigation & $198.75 \mathrm{~d}$ & $13.25 \mathrm{~d}$ & $3.1 \mathrm{~d}$ & $2015.00 \mathrm{~d}$ \\
\hline $\mathrm{LSD}_{0.05}$ & 8.87 & 0.35 & 0.06 & 49.68 \\
\hline
\end{tabular}

seed yield of different rape varieties by disturbing the growth and nutrient uptake of plants (Raza et al., 2015 a). High seed yield with proper irrigation was reported by Ullah et al. (2012). Appropriate irrigation can increase seed yield of rape from $41.7 \%$ to $62.9 \%$ as compared to less irrigated treatments (Panda et al., 2004). Biological yield is reduced up to $17.9 \%$ and $32.1 \%$ and seed yield is reduced up to $18.5 \%$ and $38.7 \%$ under mild and extreme drought stress, respectively (Gunasekara et al., 2006).

Water use efficiency (WUE) is the ratio of economic yield to the amount of water applied. WUE shows how efficiently the available water is used by the crop to produce certain amount of economic yield. WUE can be used as an indicator to evaluate the drought tolerance of crops (Araus et al., 2002). WUE is associated with many important physiological traits of plants like stomatal conductance, photosynthesis and osmotic regulation (Bacon, 2004). WUE was partially a function of rape adaptation to environmental conditions; therefore favourable agronomic practices are also very important in order to improve the WUE (Blum, 2009). Irrigating the rape with regular interval of 14 days resulted in the highest WUE (Leilah et al., 2002). Once the minimum water use of approximately $127 \mathrm{~mm}$ was achieved, seed yield of rape increased at the rate of $6.9-7.2 \mathrm{~kg} \mathrm{ha}^{-1} \mathrm{~mm}^{-1}$ (Johnston et al., 2002). Under water deficit condition, lower value of WUE was recorded in different rape varieties as compared to control treatment. Mild water stress increases the WUE of rape (Mehana et al., 2013). High value of WUE was recorded under mild water deficit stress as compared to the control treatment and low WUE under severe stress conditions (Vafabakhsh et al., 2009). However, greater reduction was observed in rape variety sensitive to drought.

Seed oil contents. The reduction of oil contents of oil seed crops under drought stress is a common incident. Under water deficit stress, oil contents of oil seed crops were observed to be reduced (Zhang et al., 2014). In an experiment on summer grown rapeseed Wright et al.
(1995) observed that early drought (at green bud stage) could lead to low oil contents in seeds as compared to the control treatment, indicating that at early stage the final oil concentration could be correlated with the distribution of assimilates to the ovule. Rapeseed yield and seed oil contents increased when optimum amount of water was applied (Canola Council of Canada, 2008). Soil moisture content also affects the rape oil content; with increasing soil water, oil contents also increased (Johnston et al., 2002). Reduction of $36.9 \%$ to $31.4 \%$ in oil contents of rape was recorded when drought stress was applied at post anthesis and seed development stages, respectively (Mailer, Cornish, 1987). Mild drought stress does not significantly decrease the seed oil contents of rape; however, severe drought stress does. Oil contents did not decline significantly $\left(2-4 \mathrm{~mm} \mathrm{day}^{-1}\right)$ under mild drought stress, while decreased considerably (4-5 $\mathrm{mm} \mathrm{day}^{-1}$ ) when stress level increased (Jensen et al., 1996).

Drought stress not only decreases the seed oil contents but also deteriorates the quality of seed. Water deficit stress also causes an increase in glucosinolates and erusic acid contents during flowering stage; hence the oil quality of rape declined (Ullah et al., 2012). Glucosinolate accumulation has been stated to be affected by water availability, particularly at seed development and maturation stage (Champolivier, Merrien, 1996). Oil contents of rape decreased while protein content increased with increasing irrigation intervals (Table 3 ).

Table 3. Oil and protein contents of rapeseed as affected by different irrigation levels (Ali et al., 2003)

\begin{tabular}{ccc}
\hline Irrigation level & Oil content & Protein content \\
\hline $\mathrm{I}_{1}$ (4 irrigations) & $45.65 \mathrm{a}$ & $20.61 \mathrm{~b}$ \\
$\mathrm{I}_{2}$ (3 irrigations) & $44.17 \mathrm{~b}$ & $20.83 \mathrm{~b}$ \\
$\mathrm{I}_{3}$ (2 irrigations) & $44.08 \mathrm{~b}$ & $21.59 \mathrm{a}$ \\
LSD $_{0.05}$ & 0.251 & 0.675 \\
\hline
\end{tabular}




\section{Management strategies for drought tolerance in rape}

Planting method. Different techniques are used in crop production to conserve water and increase water use efficiency (WUE) in order to tackle water scarcity. One of them is planting method (Shabani et al., 2013). Planting methods affect the plant population and nutrient availability (Ijaz et al., 2015). Most commonly used method for water conservation in crop plants are drill sowing (Aiken et al., 2015) raised bed planting (Kukal et al., 2010) and furrow planting (Zhang et al., 2007). Seedling establishment is a phenological stage at which drought stress could be damaging to the plants (Croser et al., 2003). Broadcasting in rape results in uneven seed distribution and leads to imbalanced availability of water, space and nutrients, poor seedling establishment and ultimately lower yield. Less moisture availability at the time of seed sowing results in poor and non-uniform seed germination and seedling emergence (Mwale et al., 2003). Drill sown rape showed better emergence and crop stand as compared to rape sown by broadcast method (Aiken et al., 2015). Furrow sowing of rape results in better growth and higher yield of rape as compared to ridge sowing method (Shabani et al., 2013). Water conservation is also high in furrow sowing. Furrow planting gave $13.7 \%$ more seed yield and $13.2 \%$ more WUE as compared to ridge sowing. More water conservation in furrow planting is due to less water evaporation (Buttar et al., 2006). Similarly Young et al. (2008) recorded more seed yield and oil percentage in drill sown rape as compared to the broadcast method.

Plant growth regulators. Plant growth regulators are organic compounds (other than nutrients) that in small amounts promote or modify physiological processes in plants. They regulate the germination, formation and distortion of roots, leaves and stems; regulate flowering, prevention or promotion of stem elongation and fruit ripening, etc. Crop plants mitigate adverse effects of water deficit stress to some extent by the exogenous application of different organic compounds (Raza et al., 2012 a). Plant growth regulators like salicylic acid, gibberellic acid and cytokinin modify the plant responses towards drought stress (Farooq et al., 2009). Foliar applied salicylic acid and putriscine significantly mitigate the adverse effects of drought on rape (Ullah et al., 2012). Drought affected plants sprayed with salicylic acid and putriscine had higher relative water contents, chlorophyll contents, carotenoid contents and proline contents as compared to untreated plants. Seed oil contents were also higher in putriscine treated plants. Similar results were reported by El-Lethy et al. (2010) in flax plants. In rapeseed, drought conditions during flowering stage resulted in higher accumulation of glucosinolates which are responsible for unpleasant and pungent oil smell (Bouchereau et al., 1996). Application of putriscine to drought treated rape significantly reduced the accumulation of glucosinolates. Erucic acid is reported to be involved in formation of heart lesions and also responsible for pungent smell of oil. Application of salicylic acid reduces the erucic acid contents in rape oil (Ullah et al., 2012).

Drought also induces oxidative damage by the formation of reactive oxygen species (Mittler, 2002). Plants ameliorate the oxidative injury by accelerating the activities of some enzymes. Some important enzymes involved in scavenging of ROS are catalase, polyphenol oxidase and ascorbate peroxidase (Ashraf, 2009). An increase in activity of catalase and polyphenol oxidase in drought affected rape was recorded when sprayed with $300 \mu \mathrm{M}$ SA as compared to untreated plants (Ahmadi et al., 2015). Similar effects of salicylic acid were reported by Hayat et al. (2008). Salicylic acid also reduces the lipid peroxidation in plants under drought (Tirani et al., 2013). Ascorbate peroxidase production increases in plants when sprayed with ascorbic acid. Ascorbate peroxidase activity increased in drought stressed rape when sprayed with 300 $\mathrm{mg} \mathrm{L}^{-1}$ ascorbic acid (Ahmadi et al., 2015). Similar effects of ascorbic acid for enhancing the activity of catalase and peroxidase were reported by Shafiq et al. (2014).

Compatible solutes are small organic molecules that help in osmotic adjustment under stressful environment. They also play an important role in scavenging of reactive oxygen species, osmoregulation and stabilization of cell membrane proteins and lipids (Kanwal et al., 2013). Some important osmoprotectants are glycinebetaine, trehalose, soluble sugars, proline, etc. (Farooq et al., 2009). Compatible solutes are reported to increase the resistance in many plants against different environmental stresses including drought (Raza et al., 2014 a). Under stressful conditions many major crops including rape do not synthesize sufficient amount of compatible solutes to mitigate the effects of stress. As a result, foliar application of these solutes to the plants is a potential strategy to minimize the adverse effects of stressful environment (Ashraf, Foolad, 2007).

Trehalose (Tre) is an important osmolyte and is reported to increase the fresh and dry weight of seedlings; relative water contents, chlorophyll contents, catalase, peroxidase, glutathione and glyoxalase activities and decrease the level of hydrogen peroxide $\left(\mathrm{H}_{2} \mathrm{O}_{2}\right)$, lipoxygenase and malondialdehyde (MDA) activities in drought affected rape plants as compared to untreated plants (Alametal., 2014). Exogenously applied glutathione increases the plant height, number of leaves, leaf dry weight, number of pods per plant and 100 seed weight in drought affected rape as compared to the untreated rape plants (Sharbat et al., 2014). Proline contents were also high in glutathione treated plants. Mehanna et al. (2013) also reported higher seed yield and WUE in drought affected rape plants sprayed with different doses of citric acid and glutamic acid as compared to un-sprayed rape plants under drought conditions. Exogenous application of glycinebetaine also develops resistance in numerous plant species against drought (Raza et al., 2014 b). Long roots, higher chlorophyll $a, b$ and carotenoids contents; seed yield, carbohydrate contents, oil contents, proline contents, total soluble sugars and lower concentration of MDA and $\mathrm{H}_{2} \mathrm{O}_{2}$ was recorded in drought stressed rape plants, when sprayed with glycinebetaine. While concentration of enzymes involved in scavenging process of ROS like ascorbate peroxidase, polyphenol oxidase, catalase, etc. were also higher in glycinebetaine treated plants (Dawood, Sadak, 2014).

Application of potassium $(K)$. One of the basic necessities for proper growth and development of a plant is the availability of essential nutrients. Application of different nutrients also reduces the damaging effects of drought stress on plants and improves the growth and physiological performance of plants (Raza et al., 2013). $\mathrm{K}$ is one of the major plant nutrients and is involved in drought mitigation of plants (Raza et al., 2015 b). Potassium improves many physiological processes by the regulation of turgor pressure, photosynthesis, translocation of assimilates to various organs and enzymes activation, thus improves drought tolerance ability of plants (Mengel, Kirkby, 2001). Application of $\mathrm{K}$ under water deficit stress has also been reported to help in enhancing the crop performance and ultimately yield. Plant experiencing the drought stress needs more 
internal K (Cakmak, 2005 a). Higher plant height, root weight, shoot weight and grain yield of rape was obtained with $120 \mathrm{~kg} \mathrm{ha}^{-1}$ of $\mathrm{K}$ as compared to 60 and $90 \mathrm{~kg} \mathrm{ha}^{-1}$ of $\mathrm{K}$ under water deficit conditions. As $\mathrm{K}$ is involved in stomatal oscillation, maintenance of photosynthesis and partitioning of photosynthates so greater plant weight and yield were observed in plants with sufficient $\mathrm{K}$ application under water deficit stress as compared to drought stresses plants without $\mathrm{K}$ application (Cakmak, $2005 \mathrm{~b}$ ).

Higher stomatal conductance was recorded in rape provided with more $\mathrm{K}$ under drought stress (Fanaei et al., 2009). Leaf RWC was also significantly affected by $\mathrm{K}$ application under water deficit stress. More RWC was recorded in different rape varieties with increasing rate of K under drought stress (Ali et al., 2014). Similar results were reported by Umar and Din (2002) that $\mathrm{K}$ application improves the RWC in drought affected plants. Higher RWC in drought affected rape is due to the positive effect of $\mathrm{K}$ on stomatal conductance, WUE and lowering of transpiration rate.

Breeding. Due to the prevalence of drought in most arid regions, resistance of crop plants against drought has always been taken into account as one of the important breeding factor for inducing drought tolerance (Talebi et al., 2009). Water is becoming limited not only in arid and drought prone areas but also in regions where rainfall is abundant. Thus, drought indices provide a measure of drought based yield loss under drought conditions in comparison to normal conditions (Mitra, 2001). Drought tolerance ability is a polygenic phenomenon and is associated with those characters of plants which are helpful for drought mitigation like root to shoot ratio, type of root system, transpiration rate, frequency and size of stomata, stomatal conductance and rate of photosynthesis (Ahmad et al., 2009). The main processes on which breeding program to improve the WUE of plants are based on are efficient uptake of available water, higher biomass production per unit water transpired and partitioning of assimilates towards the economic parts of crop plants (Condon et al., 2004).

There is little literature available at molecular genetics level for drought tolerance in rape. Varieties having higher stress tolerance index (STI), yield index (YI), yield stability index (YSI), drought resistance index (DRI) and modified stress tolerance index (MSTI) are well adapted to water deficit conditions (Khalili et al., 2012). STI is the most important criterion to select a variety for cultivation under water deficit conditions due to its highest correlation with seed yield. Twenty rape varieties were grown under different irrigation regimes and it was observed that although drought stress significantly decreased the seed yield in all varieties as compared to control treatment but varieties with high values of STI produced higher seed yield and vice versa (Rad, 2000). So, crops having minimum yield loss under drought stress are best to cultivate in arid regions.

Qualitative trait loci (QTL) is a particular portion of gene controlling a specific attribute/trait (Tanksley, 1997). Advances in molecular genetics make it easier to find the specific sites on chromosomes containing QTLs. Nowadays, most commonly used technique to find QTLs is DNA marker technology (Prioul et al., 1997). Hall et al. (2005) made QTL map of Brassica crops for WUE and photosynthetic traits and identified 30 significant QTLs. QTLs of many important traits like photosynthesis, nitrogen content, leaf thickness and number of stomata were reported to share the same location in Brassica crops (Zhang et al., 2014). Similar effects of QTLs for drought mitigation in rape were reported by Heiliger (2012).

\section{Conclusion}

Drought is the most detrimental abiotic stress affecting the plant growth and development globally. In rape, drought causes a reduction in growth by impairing germination, root growth, shoot growth, and reduced leaf area due to loss of turgor. Photosynthesis, the prime important process is also disturbed by drought mainly due to stomatal closure, reduced chlorophyll contents, restricted activity of enzymes and production of reactive oxygen species (ROS), which cause oxidative damage to membrane and organelles. Reproductive growth of rape is more sensitive to drought than vegetative growth. Drought causes a decrease in the number of pods per plant, seeds per plant, 1000 seed weight and seed yield by influencing a number of morphological and physiological traits. Adverse effects of drought can be minimized by different management practices like planting methods, foliar application of plant growth regulators, nutrients, compatible solutes and various breeding programmes for drought tolerance in rape. So, there is a need to adopt the various management techniques in order to combat the problem of drought.

Received 15052016 Accepted 17102016

\section{References}

1. Abili J., Zare S. 2014. Evaluation of antioxidant enzymes activity in canola under salt stress. International Journal of Farming and Allied Sciences, 3: 767-771.

2. Achard P., Cheng H., De Grauwe L., Decat J., Schoutteten H., Moritz T., Harberd N. P. 2006. Integration of plant responses to environmentally activated phytohormonal signals. Science, 311: 91-94. https://doi.org/10.1126/science.1118642

3. Ahmad R. T., Malik I. A., Khan I. A., Jaskani M. J. 2009. Genetic analysis of some morpho-physiological traits related to drought stress. International Journal of Agriculture and Biology, 11: 235-240.

4. Ahmad S., Raza M. A. S., Saleem M. F., Zahra S. S., Khan I. H., Ali M., Shahid A. M., Iqbal R., Zaheer M. S. 2015. Mulching strategies for weeds control and water conservation in cotton. Journal of Agriculture and Biological Sciences, 8: 299-306.

5. Ahmadi S. A. K., Ebadi A., Daneshian J., Jahanbakhsh S. Siadat S. A., Tavakoli H. 2015. Effects of irrigation deficit and application of some growth regulators on defense mechanisms of canola. Notulae Botanicae Hortica Agrobotanici Cluj-Napoca, 43: $1-10$.

6. Aiken R., Baltensperger D., Krall J., Pavlista A., Johnson J. 2015. Planting methods affect emergence, flowering and yield of spring oilseed crops in the I IS central High Plains. Indus Crons Production, 69: 273-277. https://doi.org/10.10ॅ6/j.indcrop.2015.02.025

7. Alam M. M., Nahar K., Hasanuzzaman M., Fujita M. 2014 Trehalose-induced drought stress tolerance: a comparative study among different Brassica species. Plant Omics, 7: 271-283.

8. Ali M., Bakht J., Khan G. D. 2014. Effect of water deficiency and potassium application on plant growth, osmolytes and grain yield of Brassica napus cultivars. Acta Botanica Croatica, 73: 299-314.

9. Ali N., Javidfar F., Elmira J. Y., Mirza M. Y. 2003. Relationship among yield components and selection criteria for yield improvement in winter rapeseed (Brassica napus L.). Pakistan Journal of Botany, 35: 167-174.

10. Amanullah, Marwat K. B., Shah P., Maula N., Arifullah S. 2009. Nitrogen levels and its time of application influence leaf area, height and biomass of maize planted at low and high density. Pakistan Journal Botany, 41: 761-768.

11. Araus J. L., Slafer G. A., Reynolds M. P., Royo C. 2002. Plant breeding and drought in $\mathrm{C}_{3}$ cereals: what should we breed for? Annals of Rotany. 89. 925-940

https://doi.org/10.1093/aob/mcf049

12. Ardestani H. G., Rad A. S. H. 2012. Impact of regulated deficit irrigation on the physiological characteristics of two rapeseed varieties as affected by different potassium rates. African Journal of Biotechnology, 11: 6510-6519.

13. Asada K. 1999. The water-water cycle in chloroplasts: scavenging of reactive oxygen species and dissipation of excess photons Plant Molecular Biology, 50: 601-639.

14. AshrafM.2009. Biotechnological approach of improving plant salt tolerance using antioxidants as markers. Bintechnologv Advances, 27: 84-93. https://doi.org/10.1016/j.biotechadv.2008.09.003 
15. Ashraf M., Foolad M. 2007. Roles of glycine betaine and proline in improving plant abiotic stress resistance. Environmental and Fxnerimental Rotany 59. 206-716

https://doi.org/10.1016/j.envexpbot.2005.12.006

16. Ashrat M., Harris P. J. C. 2013. Photosynthesis under stressful environments: an overview. Photosynthetica, 51: 163-190. https://doi.org/10.1007/s11099-013-002̌1-6

17. Ashrat M., Shahbaz M., Als Q. 2013. Drought-induced modulation in growth and mineral nutrients in canola (Brassica napus L.). Pakistan Journal Botany, 45: 93-98.

18. Bacon M. A. (ed.). 2004. Water use efficiency in plant biology. Oxford, UK.

19. Bajji M., Lutts S., Kinet J. M. 2001. Water deficit effects on solute contribution to osmotic adjustment as a function of leaf ageing in three durum wheat (Triticum durum Desf.) cultivars performing differently in arid conditions Plant Science 160 669-681. https://doi.org/10.1016/S0168-9452(00)00443-X

20. Blum A. 20U9. Ettective use of water (EUW) and not water-use efficiency (WUE) is the target of crop yield improvement under drought stress. Field Crons Research 112: 119-123.

https://doi.org/10.1016/j.fcr.2009.03.009

21. Bouchereau A., Clossais-Besnard N., Bensaoud A., Leport L., Renard M. 1996. Water stress effects on rapeseed quality.
Furnnean Inurnal A oronnmy 5.19-30 https://doi.org/10.1016/S1161-0301(96)02005-9

22. Boyer J. S. 1987 Plant nroductivity and envirnnment Science, 218: 443-448. https://doi.org/10.1126/science.218.4571.443

23. Buttar G. S., Thind H. S., Aujla M. S. 2006. Methods of planting and irrigation at various levels of nitrogen affect the seed yield and water use efficiency in transplanted rapeseed (Brassica napus I. ). A griculture Water Management 85: 253-260.

https://doi.org/10.1016/j.agwat.2006.05.008

24. Cakmak l. 2005 (a). The role of potassium in alleviating detrimental effects of abiotic stresses in plants. Journal of Plan Nutrition and Snil Science 168. 571-530. https://doi.org/10.1002/jpln.200420485

25. Cakmak I. 2005 (b). The role of potassium in alleviating detrimental effects of abiotic stresses by potassium nutrition under erratic rainfall conditions. Journal of Plant Nutrition, 25: 1549-1562.

26. Canola Council of Canada. 2008. Effects of moisture on canola growth. Winnipeg, Canada.

27. Champolivier L., Merrien A. 1996. Effects of water stress applied at different growth stages to Brassica napus L. var. oliefera on yield, yield components and seed quality. European Journal of Agronomy, 5: 153-160

https://doi.org/10.1016/S1161-0301(96)02004-7

28. Chaves M. M., Pereira J. S., Moroco J., Kodrıgues M. L., Recardo C., Osorio C. P. P., Pinheiro C. 2002. How plants cope with water stress in the field? Photosynthesis and growth Annals of Botany, 89: 907-916. https://doi.org/10.1093/aob/mcf105

29. Condon A. G., Richards R. A., Rebetzke G. J., Farquhar G. D. 2004 Breeding for high water-use efficiency Inurnal of Fxnerimental Botany, 55: 2447-2460. https://doi.org/10.1093/jxb/erh277

30. Croser J. S., Clarke H. J., Siddıque K. H. M., Khan I. N. 2003. Low-temperature stress: implications for chickpea (Cicer arietinum L.) imnrovement Critical Reviews in Plant Sciences, 22: 185-219. https://doi.org/10.1080/713610855

31. Dawood M. G., Sadak M. S. 2014. Physiological role of glycinebetaine in alleviating the deleterious effects of drought stress on canola plants (Brassica napus L.). Middle East Journal of Agriculture Research, 3 (4): 943-954.

32. Ebrahimian E., Bybordi A. 2012. Influence of ascorbic acid foliar application on chlorophyll, flavonoids, anthocyanin and soluble sugar contents of sunflower under conditions of water deficit stress. Journal of Food Agriculture and Environment, 10: 1026-1030.

33. El-Lethy S. R., Hasnaa S. A. Y., Talaat I. M. 2010. Physiological effect of some antioxidant on flax plant (Linum usitatissimum L.). World Journal of Agricultural Sciences, 6: 622-629.

34. Emam Y., Niknejad M. 2004. An introduction to the physiology of crop yield. Shiraz, Iran.

35. Fanaei H. R., Galavi M., Kafi M., Bonjar A. G. 2009. Amelioration of water stress by potassium fertilizer in two oilseed species. International Journal of Plant Production, 3: 41-54.

36. Faraji A., Latifi N., Soltani A., Shirani-Rad A. H. 2009. Seed yield and water use efficiency of canola (Brassica napus L.) as affected by high temperature stress and supplemental irrigation. affected by high temperature stress and supplem https://doi.org/10.1016/j.agwat.2008.07.014

37. Farooq M., Wahid A., Lee D. J. 200Y. Exogenously applied polyamines increase drought tolerance of rice by improving leaf water status, photosynthesis and membrane properties. Acta Physinlogiae Plantarum 31.937-945

https://doi.org/10.1007/s11738-009-0307-2

38. Farouk S. 2011 . Usmotic adjustment in wheat flag leaf in relation to flag leaf area and grain yield per plant. Stress Physiology and Biochemistry, 7: 117-138.

39. Ghobadi M., Bakhshandeh M., Fathi G., Gharineh M. H. Alamisaeed K., Naderi A., Ghobadi V. 2006. Short and long periods of water stress during different growth stages of canola (Brassica napus L.). Effect on yield, yield components, seed oil and nroteincontents A ornnomv Inurnal, 5: 336-341. https://doi.org/10.3923/ja.2006̆.336.341
40. Gill S. S., Tuteja N. 2010. Reactive oxygen species and antioxidant machinery in abiotic stress tolerance in crop plants. Plant Physiolnov and Rinchemistry 48 (1) ) 909-930.

https://doi.org/10.1016/j.plaphy.2010.08.016

41. Gul H., Ahmad R. 2004. Effect of different irrigation intervals on growth of canola (Brassica napus L.) under different salinity levels. Pakistan Journal of Botany, 36: 359-372.

42. Gunasekara C. P., Martin L. D., French R. J., Siddique K. H., Walton M. G. 2006. Genotype by environmental interactions of Indian mustard (Brasica juncea L.) and canola (Brassica napus L.) in Mediterranean type environments. Crop growth and seed vield Furnean Iournal of A oronomy 25: 1-12. h̆ttps://doi.org/10.1016/j.eja.2005.08.002

43. Habibi G. 2015. Contrastive response of Brassica napus L. to exogenous salicylic acid, selenium and silicon supplementation under water stress. Archives of Binlngical Sciences, 67: 397-406. https://doi.org/10.2298/ABS140411006H

44. Hadi F., Ayaz M., Ali S., Shatiq M., Ullah R., Jan A. U. 2014. Comparative effect of polyethylene glycol and mannitol induced drought on growth (in vitro) of canola (Brassica napus), cauliflower (Brassica oleracea) and tomato (Lycopersicon esculentum) seedlings. International Journal of Biosciences, 9: 34-41.

45. Hall N. M., Griffiths H., Corlett J. A., Jones H. G., Lynn J., King G. J. 2005. Relationships between water-use traits and photosynthesis in Brassica oleracea resolved by quantitative genetic analysis. Plant Rreeding. 124: 557-564. https://doi.org/10.1111/j.1439-05́23.2005.01164.x

46. Haque M. M., Mackill D. J., Ingram K. T. 1992. Inheritance of leaf enicuticular wax content in rice Cron Sciences, 32: 865-868. https://doi.org/10.2135/cropsci1992.0011183X003200040006x

47. Hassanzadeh M., Naderei M., Shiraneirad A. 2005. Evaluation effects of drought stress on yield and yield components of autumn rapeseed cultivars in Isfahan. Journal of Agricultural Sciences, 1: 51-62.

48. Hayat S., Hasan S. A., Fariduddin Q., Ahmad A. 2008. Growth of tomato (Lycopersicon esculentum) in response to salicylic acid under water stress. Inurnal of Plant Interaction, 3: 297-304. https://doi.org/10.1080/17429140802320797

49. Heiliger A. 2012. Quantitative trait locus mapping of yield and yield components in canola (Brassica napus L.) under irrigated and rainfed treatments: $\mathrm{Ph}$. D. thesis. Colorado State University, USA.

50. Heshmat O., Saeed H. A., Fardin K. 2011. The improvement of seed germination traits in canola (Brassica napus L.) as affected by saline and drought stress. Journal of Agriculture Technology, 7: $611-622$.

51. Hosseini M., Hassibi P. 2011. Effects of water deficit stress on several quantitative and qualitative characteristics of canola (Brassica napus L.) cultivars. Notulae Scientia Biologicae, 3: 120-125.

52. Huax X. J., Vande-Cotte B., Montayel M. V., Verbragen N. 1997. Developmental regulation of proline-5-carboxylate reluctance gens exnression in Arahidonsis. Plant Phvsiology, 114: 12151224. https://doi.org/10.1104/pp.114.4.1215

53. Ijaz M., Raza M. A. S., Ali S., Ghazi K., Yasir T. A., Saqib M., Naeem M. 2015. Differential planting density influences growth and yield of hybrid maize (Zea mays L.). Journal of Environmental and Agriculture Sciences, 2: 1-5.

54. Jabeen F., Shahbaz M., Ashraf M. 2008. Discriminating some prospective cultivars of maize (Zea mays L.) for drought tolerance using gas exchange characteristics and prolinecontents as physiological markers. Pakistan Journal of Botany, 40: 2329-2343.

55. Jensen C. R., Mogensen V. O., Fieldsen J. K., Thage J. H. 1996. Seed glucosinolate, oil and protein contents of field-grown rape (Brassica napus L.) affected by soil drying and evaporative demand. Field Crons Research 47: 93-105. https://doi.org/10.1016/0378-4290(96)00026-3

56. Johnston A. M., Janaka D. L., Miller P. R., Brandt S. A., Nielsen D. C., Lafond G. P., Riveland N. R. 2002. Oilseed crops for semiarid cropping systems in the Northern Great Plains. Agronomy Journal, 94: 231-240 https://doi.org/10.2134/agronj2002.0231

57. Jones H. G., Hlowers ' I. J., Jones M. B. 1991. Plants under stress: biochemistry, physiology and ecology and their application for plant improvement. New York, USA.

58. Kage H., Kochler M., Stutzel H. 2004. Root growth and dry matter partitioning of cauliflower under drought stress conditions: measurement and simulation. Furnean Inurnal of A oronomy, 20: 379-394. https://doi.org/10.1016/S1161-0301(03)00061-3

59. Kanwal H., Ashrat M., Hameed M. 2013. Water relations and ionic composition in the seedlings of some newly developed and candidate cultivars of wheat (Triticum aestivum L.) under saline conditions. Pakistan Journal of Botany, 45: 1221-1227.

60. Khalid A., Arshad M., Zahir Z. A. 2006. Phytohormones: microbial production and applications. Netal U. (ed.). Biological approaches to sustainable soil systems. Boca Raton. USA, p. 207-220. https://doi.org/10.1201/9781420017113.ch14

61. Khalili M., Naghavi M. R., Aboughadareh A. P., 'Ialebzadeh S. J. 2012. Evaluating of drought stress tolerance based on selection indices in spring canola cultivars (Brassica napus L.). Journal of Agriculture Science 4: 78-85. https://doi.org/10.5539/jas.v4n11p78 
62. Khan M. A., Ashraf M. Y., Mujtaba S. B., Shirazi M. U., Khan M. A., Shereen A., Kaleri G. M. 2010. Evaluation of high yielding canola type Brassica genotypes/mutants for drough tolerance using physiological indices as screening tool. Pakistan Journal of Botany, 42: 3807-3816.

63. Kheradmand M. A., Fahraji S. S., Fatahi E., Raoofi M. M. 2014 Effect of water stress on oil yield and some characteristics of Brassica napus. International Research Journal of Applied and Basic Sciences, 8: 1447-1453.

64. Kukal S. S., Yadav S., Humphreys E., Kaur A., Singh Y., Thaman S., Singh B., Timsina J. 2010. Factors affecting irrigation water savings in raised heds in rice and wheat Field Crop Research, 118: 43-50. https://doi.org/10.1016/j.fcr.2010.04.003

65. Kumar A., Singh D. P. 19y8. Use of physiological indices as screening technique for drought tolerance in oilseed Brassica snecies. Annals of Rotany, 81:413-470. https://doi.org/10.1006/anbo.1997.0573

66. Leilah A. A., AI-Khateeb S. A., AI-N1em A., Al-Tahbet A. 2002 Response of some canola cultivars to drought in the region of Low Holy Mosques. Agriculture and water resources development. King Faisal University, Saudi Arabia, p. 28-30.

67. Lizana C., Wentworth M., Martinez J. P., Villegas D., Meneses R., Murchie E. H., Pastenes C., Lercari B., Vernieri P., Horton P., Pinto M. 2006. Differential adaptation of two varieties of common bean to ahintic stress. Inurnal of Fxnerimental Botany, 57: 685-697. https://doi.org/10.1093/jxb/erj062

68. Ludlow M. M., Muchow K. C. 1990. A critical evaluation of the traits for improving crop yield in water limited environments. Advances in A gronomy 43: 107-153

https://doi.org/10.1016/S0065-2113(08)60477-0

69. Ma1ler K. J., Cornish P. S. 198\% Ettects of water stress on glucosinolate and oil concentrations in the seeds of rape (Brassica napus L.) and turnip rape (Brassica rapa L. var. silvestris [Lam.] Rriogs) Animal Production Science, 27: 707-711. https://doi.org/10.1071/EA9870707

70. Majumdar S S. Ghosh B., Glick R., Dumbroff E. B. 1991. Activities of chlorophyllase, phosphoenolpyruvate carboxylase and ribulose-1,5-bisphosphate carboxylase in the primary leaves of soybean during senescence and drought. Plant Physiolngy 81: 473-480. https://doi.org/10.1111/j.1399-3054.1991.tb05087.x

71. Malcolm J. M., Doug W. S. 2002. Heat stress durıng Howerıng in summer Rrassica Cron Sciences 42:797-803.

https://doi.org/10.2135/cropsci2002.0797

72. Malık 1. A., Sana-UIlah, Malık S. 2006. Genetic linkage studies of drought tolerant and agronomic traits in cotton. Pakistan Journal of Botany, 38 (5): 1613-1619.

73. Martinez J. P., Silva H., Ledent J. F., Pinto M. 2007. Effect of drought stress on the osmotic adjustment, cell wall elasticity and cell volume of six cultivars of common beans (Phaseolus vulgaris $\mathrm{I}$..). Furnean Inurnal of A gronomy, 26: 30-38. https://doi.org/10.1016/j.eja.2006.08.003

74. Mehanna H. M., Hussein M. M., Gaballah M. S. 2013. Drough alleviation using glutathione in canola plants. International Journal of Advanced Research, 2 (9): 679-685.

75. Mengel K., Kirkbv F. A. 2001. Princinles of nlant nutrition ( $5^{\text {th }}$ ed.). Netherlands. https://doi.org/10.1007/978-94-010-1009-2

76. Mirzaee M., Moienı A., Ghanat1 F. 2013. Ettects of drought stress on the lipid peroxidation and antioxidant enzyme activities in two canola (Brassica napus L.) cultivars. Journal of Agriculture Science and Technology, 15: 593-602.

77. Mitra J. 2001. Genetics and genetic improvement of drought resistance in crop plants. Current Science, 80: 758-762.

78. Mittler R. 2002. Oxidative stress, antioxidants and stress tolerance. Trends in Plant Science 7: 405-410 https://doi.org/10.1016/S1360-1385(02)02312-9

79. Mondal S. K., Khajuria M. K. 2000. Genetıc analysis for yield attributes in mustard. Environment and Ecology, 18: 1-5.

80. Munne-Bosch S., Penuelas J. 2003. Photo- and antioxidative protection during summer leaf senescence in Pistacia lentiscus L. grown under Mediterranean field conditions Annals of Botany, 92 (3): 385-391. https://doi.org/10.1093/aob/mcg152

81. Munoz-Perea C. G., Allen R. G., Westermann D. I., Wright J. L. Singh S. P. 2007. Water use efficiency among dry bean landraces and cultivars in drought-stressed and non-stressed environments. Funhytica 155: 393-402

https://doi.org/10.1007/s10681-006-9340-Z

82. Mwale S. S., Hamusimb1 C., Mwansa K. 2003. Germination, emergence and growth of canola (Brassica napus L.) in response to nsmotic seed nriming. Seed Science and Technology, 31: 199-206. https://doi.org/10.15258/sst.2003.31.1.21

83. Nasab H. M., Siadat S. A., Nader1 A., Lack S., Modhej A. 2014 Effect of drought stress and nitrogen levels on yield, stomata conductance and temperature stability of rapeseed (canola) genotypes. Advances in Environmental Biology, 8: 1239-1247.

84. Nasri M., Khalatbari M., Zahedi H., Paknejad F., TohidiMoghadam H. R. 2008. Evaluation of micro and macro elements in drought stress condition in cultivars of rapeseed (Brassica napus L.). American Journal of Agricultural and Riolngical Sciences, 3 (3): 579-583. https://doi.org/10.3844/ajabssp.2008.579.583

85. Nasrullah M., Khan M. B., Ahmad K., Ahmad S., Hanıt M. Nazeer W. 2011. Sustainable cotton production and water economy through different planting methods and mulching techniques. Pakistan Journal of Botany, 43 (4): 1971-1983.

86. Ober E. S., Bloa M. L., Clark C. J. A., Royal A., Jaggard K. W. Pidgeon J. D. 2005. Evaluation of physiological traits as indirect selection criteria for drought tolerance in sugar beet. Field Crops Research 91 (?): 231-7.49

https://doi.org/10.1016/j.fcr.2004.07.012

87. Panda B. B., Bandyopadhyay S. K., Shivay Y. S. 2004. Effect of irrigation level, sowing dates and varieties on yield attributes, yield, consumptive water use and water-use efficiency of Indian mustard (Brassica juncea). Indian Journal of Agricultural Sciences, 74: 339-342.

88. Parry M. A., Andralojc P. J., Khan S., Lea P. J., Keys A. J. 2002 Rubisco activity: effects of drought stress. Annals of Botany, 89: 833-839. https://doi.org/10.1093/aob/mcf103

89. Pasban Eslam B., Shakiba M. K., Neyshabouri M. R., Moghadam M., Ahmadi M. R. 2000. Evaluation of physiological indices as a screening technique for drought resistance in oilseed rape. Pakistan Academy of Sciences Journal, 37 (2): 143-152 (in Farsi).

90. Patil M. D., Biradar D. P., Patil V. C., Janagoudar B. S. 2011 Response of cotton genotypes to drought mitigation practices. American-Eurasian Journal of Agriculture and Environmental Sciences, 11: 360-364.

91. Prioul J. L., Quarrie S., Causse M., De-Vienn D. 1997. Dissecting complex physiological functions through the use of molecular quantitative genetics. Journal of Exnerimental Botany, 48: 11511163. https://doi.org/10.1093/jxb/48.6.1151

92. Qaderı M. M., Kurepın L. V., Keid D. M. 2006. Growth and physiological responses of canola (Brassica napus) to three components of global climate change: temperature, carbon dioxide and drought. Plant Physiology, 128: 710-721. https://doi.org/10.1111/j.1399-3054.2006.00804.x

93. Kad A. H. S. 2000. Study on drought stress tolerance in rapeseed varieties based on drought stress tolerance indices. International Journal of Engineering Research and Applications, 2: 1668-1673.

94. Rahman S., Shaheen M. S., Rahman M., Malik T. A. 2000 Evaluation of excised leaf water loss and relative water content as screening techniques for breeding drought resistant wheat. Pakistan . Inurnal of Rinlnoical Sciences. 3: 663-665. https://doi.org/10.3923/pjbs.2000.663.665

95. Kahnema A. A., Bakhshandeh A. M. 2006. Determination of optimum irrigation level and compatible canola varieties in the Mediterranean environment. Asian Journal of Plant Sciences, 5 : 543-546. https://doi.org/10.3923/ajps.2006.543.546

96. Ram B., Singh V. V., singh B. K., Priyamedha, Kumar A., Singh D. 2015. Comparative tolerance and sensitive response of Indian mustard (Brassica juncea L. Czern and Coss) genotypes to high temperature stress. SABRAO Journal of Breeding and Genetics, 47 (3): 315-325.

97. Rastegar M. A. 2004. Agronomy of Industrial Plants. Tehran, Iran.

98. Raza M. A. S., Saleem M. F., Ashraf M. Y., Ali A., Asghar H. N. 2012 (a). Glycinebetaine applied under drought improved the physiological efficiency of wheat (Triticum aestivum L.) plant. Soil and Environment, 31 (1): 67-71.

99. Raza M. A. S., Saleem M. F., Anjum S. A., Khaliq T., Wahid M. A 2012 (b). Foliar application of potassium under water deficit conditions improved the growth and yield of wheat (Triticum aestivum L.). Journal Animal and Plant Sciences, 22: 431-437.

100. Raza M. A. S., Saleem M. F., Shah G. M., Jamil M., Khan I. H 2013. Potassium applied under drought improves physiological and nutrient uptake performances of wheat (Triticum aestivum L.). Journal of Soil Science and Plant Nutrition, 13: 175-185.

101. Raza M. A. S., Saleem M. F., Shah G. M., Khan I. H., Raza A. 2014 (a). Exogenous application of glycinebetaine and potassium for improving water relations and grain yield of wheat under drought. Journal of Soil Science and Plant Nutrition. 14: 348364. https://doi.org/10.4067/s0718-95162014005000028

102. Raza M. A. S., Saleem M. F., Moazzam J., Imran H. K. 2014 (b) Impact of foliar applied glycinebetaine on growth and physiology of wheat (Triticum aestivum L.) under drought conditions. Pakistan Journal of Agricultural Sciences, 51: 327-334.

103. Raza M. A. S., Shahid A. M., Ijaz M., Khan I. H., Saleem M. F., Ahmad S. 2015 (a). Studies on canola (Brassica napus L.) and camelina (Camelina sativa L.) under different irrigation levels. ARPN Journal of Agricultural and Biological Science, 10 (4): 130-138.

104. Raza M. A. S., Saleem M. F., Khan I. H. 2015 (b). Combined application of glycinebetaine and potassium on the nutrient uptake performance of wheat under drought stress. Pakistan Journal of Agricultural Sciences, 52: 19-26.

105. Reddy A. R., Chaitanya K. V., Vivekanandan M. 2004. Droughtinduced responses of photosynthesis and antioxidant metabolism in higher nlants. Journal of Plant Phvsiology, 161: 1189-1202. https://doi.org/10.1016/j.jplph.2004.01.013

106. Kesh H. M. 2U12. Hydroponic tood production: a definitive guidebook for the advanced home gardener and the commercial hydroponic grower ( $7^{\text {th }}$ ed.). https://doi.org/10.1201/b12500

107. Reyes S. U. 2007. Canola oil (http://www.ats.agr.gc.ca/asean/4359 e).

108. Robertson M. J., Holand J. F. 2004. Production risk of canola in the semiarid tronics of Australia. Cron and Pasture Science, 55: 525-538. https://doi.org/10.1071/AR03219 
109. Sánchez-Blanco M. J., Rodriguez P., Morales M. A., Ortuno M. F., Torrecillas A. 2002. Comparative growth and water relations of Cistusalbidus and Cistusmonspeliensis plants during water deficit conditions and recovery. Plant Science. 162: 107-113. deficit conditions and recovery. Plant Science.
https://doi.org/10.1016/S0168-94452(01)00540-4

110. Sánchez-Kodriguez E., Kuiz J. M., Ferreres F., Moreno D. A 2012. Phenolic profiles of cherry tomatoes as influenced by hydric stress and rontstock technigue. Fond Chemistrv, 134: 775-782. https://doi.org/10.1016/j.foodchem.2012.02.180

111. Shabani A., Sepaskhah A. K., Kamgar-Haghighi A. A. 2013. Growth and physiologic response of rapeseed (Brassica napus L.) to deficit irrigation, water salinity and planting method. International Journal of Plant Production, 7 (3): 569-596.

112. Shafiq S., Akram N. A., Ashraf M., Arshad A. 2014. Synergistic effects of drought and ascorbic acid on growth, mineral nutrients and oxidative defense system in canola (Brassica napus L.) nlants. Acta Physiolngiae Plantarum. 36: 1539-1553. https://doi.org/10.1007/s11738-014-1530-z

113. Shahverdikandı M. A, Iobeh A., Godehkahriz S. J., Rastegar Z 2011. The study of germination index of canola cultivars for drought resistance. International Journal of Agronomy and Plant Production, 2 (3): 89-95.

114. Shao H. B., Chu L. Y., Jaleel A., Zhao C. X. 2008. Water-deficit stress-induced anatomical changes in higher nlants. Comntes Rendus Biologies, 331: 215-225. https://doi.org/10.1016/j.crvi.2008.01.002

115. Sharbat L. M., Mehanna H. M., Gaballah M. S. 2014. Drought alleviation using glutathione in canola plants. International Journal of Advanced Research, 2 (9): 679-685.

116. Sharma K. D., Kuhad M. S., Nandwal A. S. 1993. Influence of K nutrition on Brassica genotypes in response to water stress. Plant Physiology and Biochemistry, 2: 110-115.

117. Sharp R. E., LeNoble M. E. 2002. ABA, ethylene and the control of shoot and root growth under water stress. Inurnal of Fxnerimental Botany, 53: 33-37. https://doi.org/10.1093/jexbot/53.366.33

118. Silva A. E. C., Gore M. A., Sanchez P. A., French A. N., Hunsaker D. J., Salvucci M. E. 2012. Decreased $\mathrm{CO}_{2}$ availability and inactivation of Rubisco limit photosynthesis in cotton plants under heat and drought stress in the field. Environmental and Fxnerimental Rotany 83: 1-11 https://doi.org/10.1016/j.envexpbot.2012.04.001

119. Soomroo M. H., Markhand G. S., Soomro B. A. 2011. Screening Pakistani cotton for drought tolerance. Pakistan Journal of Botany, 44: 383-388.

120. Talebi R., Fayaz F., Naji A. M. 2009. Effective selection criteria for assessing drought stress tolerance in durum wheat (Triticum durum Desf.). General and Applied Plant Physiology, 35 (1-2): 64-74.

121. Tanksley S. D. 1997. Mapping polygenes. Annual Review of Genetics 27: 205-733 https://doi.org/10.1146/annurev.ge.27.120193.001225

122. Iezara W., Mitchell V. J., Driscoll S. D., Lawlor D. W. 1999. Water stress inhibits plant photosynthesis hy decreasing counling factor and ATP. Nature, 401: 914-917. https://doi.org/10.1038/44842
123. Tirani M. M., Nasibi F., Kalantari K. M. 2013. Interaction of salicylic acid and ethylene and their effects on some physiological and biochemical parameters in canola plants (Brassica napus L.). Photosynthetica 51:411-418

https://doi.org/10.1007/s11099-013-0041-2

124. Iohıd1-MoghadamH.K., Shiran1-KadA.H., Nour-Mohammadi G., Habibi D., Mashhadi-Akbar-Boojar M. 2009. Effect of super absorbent application on antioxidant enzyme activities in canola (Brassica napus L.) cultivars under water stress conditions. American Inurnal of Agriculture and Rinlngical Sciences, 4 (3): 215-223. https://doi.org/10.3844/ajabssp.2009.215.223

125. Ullah F., Bano A., Nosheen A. 2012. Etfects of plant growth regulators on growth and oil quality of canola (Brassica napus L.) under drought stress. Journal of Botany, 44: 1873-1880.

126. Umar S., Din M. 2002. Genotypic differences in yield and quality of groundnut as affected by potassium nutrition under erratic rainfall conditions. Inurnal of Plant Nitrition, 25: 1149-1162. https://doi.org/10.1081/PLN-120005407

127. Vatabakhsh J, Nasırı Mahallatı M, Koocheki A, Azizi M. 2009. Effects of water deficit on water use efficiency and yield of canola cultivars (Brassica napus L.). Iranian Journal of Field Crops Research, 7 (1): 297-304 (in Farsi).

128. Waheed A. 2014. Screening and selection of tomato genotypes/ cultivars for drought tolerance using multivariate analysis. Pakistan Journal of Botany, 46: 1165-1178.

129. Wright P. R., Morgan J. M., Jessop R. S., Cass A. 1995. Comparative adaptation of canola (Brassica napus) and Indian mustard (B. juncea) to soil water deficits: yield and yield comnonents. Field Crons Research 42 (1): 1-13. https://doi.org/10.1016/0378-4290(95)000'13-G

130. Yang C. J., Zhang X. K., Lou C. S., Cheng Y., Zheng P. Y., Li G. Y. 2007 . Effects of drought simulated by PEG-6000 on germination and seedling growth of rapeseed (Brassica napus L.). Chinese Journal of Oil Crop Sciences, 29: 425.

131. Young F. L., Bewick L. S., Pan W. L. 2008. Systems approach to crop rotation research: guidelines and challenges. Crop rotation, chapter 2, p. 41-69.

132. Zakirullah Z., Swati Z. A., Ahamd A., Raziuddin R. 2000. Morpho-physiological response of selected Brassica line to moisture stress Pakistan Inurnal of Riolnoical Sciences, 3: 130 132. https://doi.org/10.3923/pjbs.2000.130.132

133. Zhang J., Sun J., Duan A., Wang J., Shen X., Liu X. 2007. Effects of different planting patterns on water use and yield performance of winter wheat in the Huang-Huai-Hai plain of China Agricultural Water Management, 92: 41-47. https://doi.org/10.1016/j.agwat.2007.04.007

134. Zhang X., Lu G., Long W., Lou X., Li F., Nishio T. 2014. Recent progress in drought and salt tolerance studies in Rrassica crons. Breeding Science, 64: 60-73. https://doi.org/10.1270/jsbbs.64.60

135. Zingaretti S. M., Inacio M. C., Pereira L. M., Paz I. A., Franca S. C. 2013. Responses of organisms to water stress. Akinci S. (ed.). Preto, Brazil, p. 242-245.

ISSN 1392-3196 / e-ISSN 2335-8947

Zemdirbyste-Agriculture, vol. 104, No. 1 (2017), p. 85-94

DOI $10.13080 /$ z-a.2017.104.012

\title{
Sausros sukelto streso mažinimo būdai aliejinių rapsụ pasèliuose: apžvalga
}

\author{
M. A. S. Raza' ${ }^{1}$ A. M. Shahid', M. F. Saleem², I. H. Khan', S. Ahmad', M. Ali', R. Iqbal' \\ ${ }^{1}$ Islamo universiteto žemès ūkio ir aplinkos mokslų kolegija, Pakistanas \\ ${ }^{2}$ Pakistano žemès ūkio universitetas \\ ${ }^{3}$ Ghazi universiteto žemès ūkio kolegija, Pakistanas
}

\section{Santrauka}

Rapsas (Brassica napus L.) yra visame pasaulyje svarbus aliejinis augalas. Sausra yra žalingiausias aplinkos veiksnys, veikiantis augalus nuo sudygimo iki brandos. Labai svarbu įvertinti sausros poveikị ir klimato kaitos ịtaką rapsų auginimui. Vandens trūkumo stresas veikia rapsu augalu morfologiją, fiziologiją ir vystymąsi. Straipsnio tikslas pateikti sausros streso poveikio rapsų augimui, fiziologiniams procesams, derliaus ir kokybės rodikliams apžvalgą. Trumpalaikiam arba ilgalaikiam drègmès stygiui pasireiškiant kritiniais augalų vystymosi tarpsniais, gali būti neigiamai paveikti svarbūs jų fiziologiniai procesai, sąlygojantys, pavyzdžiui, lapų ploto, šaknų, stiebų augimo, atskirto lapo vandens, santykinio vandens kiekio, fotosintezès ir vandens naudojimo efektyvumo sutrikimus, gaminant reaktyvų deguonį, mažinant žiotelių laidumą, ardant chlorofilą ir kitus pigmentus. Rapsai vandens trūkumui yra jautresni reprodukciniu tarpsnių metu - tai turi įtakos derliui ir aliejaus kokybei. Straipsnyje aptariamos ir svarbios sausros valdymo strategijos, galinčios sumažinti sausros stresą rapsų pasèliuose - specifinių tirpalų (aminorūgščių), maisto medžiagų, augimo reguliatorių naudojimas, įvairių sèjos metodų taikymas.

Reikšminiai žodžiai: Brassica napus, poveikis, sausros stresas, valdymas. 